\title{
STUDY OF USER'S RESPONSE ON THE PEDESTRIAN BRIDGE IN PEKANBARU CITY
}

\author{
Yulia Rahmawati $^{a)}$, Yohannes Firza ${ }^{\left.a^{*}\right)}$ \\ ${ }^{a)}$ Universitas Riau, Pekanbaru, Indonesia \\ ${ }^{*}$ Corresponding Author: yfirzal@eng.unri.ac.id
}

Article history: received 30 September 2020; revised 15 October 2020; accepted 26 October2020

\begin{abstract}
A pedestrian bridge in urban areas exists not only to overcome crossing between people and vehicle but also gives a sense of security and comfort for its users. With a variety of user characteristics, the bridge has also used for other informal purposes. This phenomenon becomes interesting to study how the users respond to the various uses of the bridge. By using accidental sampling method for one hundred respondents, the field data has analysed in a simple linear regression model with data processing software. The result shows the safety, security, comfort, continuity and attractiveness are the primary considerations of users in utilizing the pedestrian bridge. Even though the physical condition has found less-expected, the user's response has generally categorized as sufficient.
\end{abstract}

Keywords: pedestrian bridge, pedestrians, user's response

\section{INTRODUCTION}

In improving urban quality, it is an urge to provide facilities to support the movement of people and goods that meets safety requirements, especially facilities for pedestrians [1]. The pedestrian facilities also require supporting facilities such as zebra crossing facilities, pelican crossing, and pedestrian bridge [2]. In the context of this paper, pedestrians are willing to use the pedestrian bridge if security is guaranteed, and the walking distance does not increase too far [3]. So providing a good pedestrian bridge becomes a logical option for urban areas in overcoming traffic problems and creating a sense of security, comfort, accessibility of safety, and convenience.

To a certain degree, pedestrians who are crossing main roads in urban areas have the potential to raise conflicts with vehicle movement, contribute to traffic congestion, and to become an element of road accidents [4]. In overcoming crossing with the vehicles' movement, the provision of the pedestrian bridge has seen as one of the practical options [5] [6]. The presence and use of the pedestrian bridge are also assumed to be able to provide a sense of security and comfort for pedestrians.

However, the existence of the pedestrian bridge has also been utilized in many ways by its users [7]. Aside from being a facility to cross the road, users with a variety of characters also make use of the pedestrian bridge for various informal activities such as a place for street vendors to sell, a gathering place for homeless people, and a spot where people can sit. Furthermore, the pedestrian bridge is the location of criminal cases such as harassment, fighting, and pickpocketing. This phenomenon is quite common in urban areas that are poorly controlled and controlled, including the pedestrian bridge in Pekanbaru City. Therefore, research related to the pedestrian bridge facilities will be essential to find out how far it has used and how the community responds to the use of the pedestrian bridge.

Study on the pedestrian bridge in urban areas is a research topic that has been done previously such as research that investigate on the practical usage and the variables that influence on the using of the pedestrian bridge [8] [9] and how pedestrian behaviour towards the use of the pedestrian bridge [10]. Other research related to the accessibility of the pedestrian bridge for disable people [11] and how pedestrians respond to the pedestrian bridge in urban areas [12].

At the theoretical level, response as behaviour is a consequence of the previous action as a response or answer to a particular problem. The response is a form of communication that affects [13] or responses that occur if a factor to fulfilled that does not only originate from the surrounding stimulus. The stimulus also depends on internal factors and external factors. The response can also interpret as an act that is the final result of the existence of stimulus or stimulation. Thus, a person's response possible to be positive or negative or can be active or passive, which can undoubtedly be measured [14].

In this paper, the user's response is defining as a form of behaviour, and as a reaction to the stimulus around the existence of the pedestrian bridge as part of the perceptions, knowledge, awareness, and attitudes of the users of the pedestrian bridge. This will lead to whether the pedestrian bridge users will respond with action or not. Therefore, research becomes interesting to measure the response of pedestrian bridge users. 


\section{RESEARCH METHODS}

This research has used a quantitative methodology in the descriptive form to explain the phenomenon of the existence of the pedestrian bridge in Pekanbaru City. Population data are indefinite (not measurable) [15] using incidental sampling techniques for 100 respondents [16]. Field data obtained by questionnaire on the Likert scale [17] and strengthened by observation, recording phenomena of the activities of the pedestrian bridge users in the field systematically and in a participatory/non-participative manner. Data have analysed in a simple linear regression model [18] with the analysis of the determination index and the help of SPSS data processing software [19] [20]. The results of data analysis have tested by validity, reliability, normality, t-test [17].

\section{RESULTS AND DISCUSSION}

The pedestrian bridge is a bridge that has intended for pedestrian traffic [21]. The pedestrian bridge is defining as a building that complements the road that serves to give the interrupted traffic at both ends of the way due to obstacles in the form of rivers, channels, canals, straits, valleys and crossing roads and railways. As an instrument of circulating horizontal links, the shape of the bridge begins from the primitive era with a simple system and develops along with technological developments [22].

The pedestrian bridge as a public facility is a consequence of the development of cities such as the need for the availability of public facilities and infrastructure services to the community. However, this facility can also have various impacts in efforts to meet some of the needs or desires for all [23]. Therefore, it is essential to review the response to the existence of pedestrian bridge facilities in urban areas.

To find out how far the pedestrian bridge has used and how users have responded to the pedestrian bridge utilization, the field of research began with a mapping of the existence and distribution of the pedestrian bridge in Pekanbaru (figure 1). There are 11 pedestrian bridges with an average construction life of 8 years, and in poor physical conditions (Table 1).

The data field retrieval for further analysis process has conducted by focusing on the five most crowded pedestrian bridge conditions used on regular working days. The results of the field survey show that there are approximately 700 users of the pedestrian bridge per day.

The tabulation of the questionnaire showed consideration factors in the use of the pedestrian bridge sequentially based on the elements of safety, security, comfort, fluency, and attractiveness (figure 2). The tabulated data also hinted at the level of safety factor at five the pedestrian bridge through respondents, still not in line with the expectations of the pedestrian bridge users. This indication is shown through four of the six safety indicators that are still of sufficient category, while the other two indicators; the availability of pedestrian path to the pedestrian bridge and adequate the pedestrian bridge height is in a good grade. But the average value for the safety of the pedestrian bridge users only reached 3.20 , which has included in the sufficient category (Table 2).

The safety factor should be the primary indicator for the function and users of the pedestrian bridge. Furthermore, four out of five safety indicators have categorized as not useful. These results indicate that if the safety factor with an average value of 2.5 can interpret as needing to get more severe security attention because the pedestrian bridge has the potential to endanger the user (Table 3).

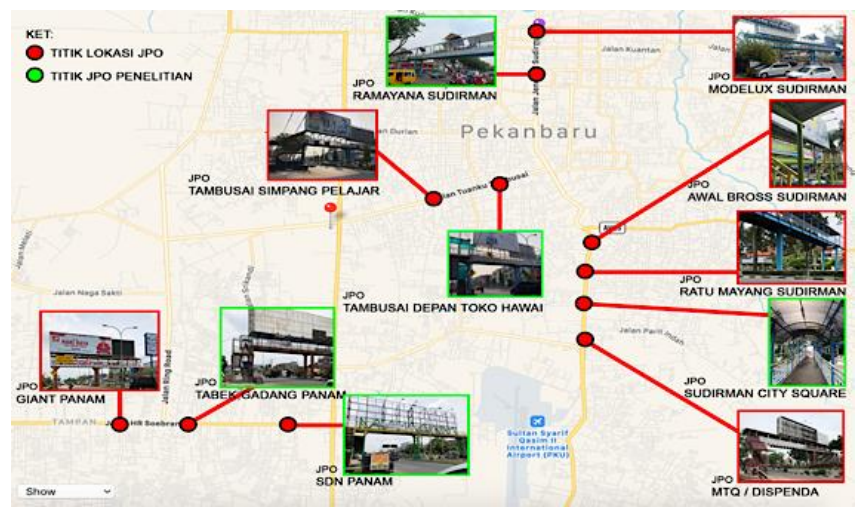

Figure 1. The pedestrian bridges location in Pekanbaru City

Table 1. The Ownership Of The Pedestrian Bridge

\begin{tabular}{lllc}
\hline No & \multicolumn{1}{c}{ Location } & \multicolumn{1}{c}{ Position } & Owner \\
\hline 1 & Jln Jend. Sudirman & Modelux Store & Expired \\
2 & Jln Jend. Sudirman & Plaza Suka Ramai & PT. CPI \\
3 & Jln Jend. Sudirman & Awal Bross Hospital & PT. CPI \\
4 & Jln Jend. Sudirman & Sudirman Square & Expired \\
5 & Jln Jend. Sudirman & Ratu Mayang Garden Hotel & Expired \\
6 & Jln Jend. Sudirman & Ex-MTQ & Expired \\
7 & Jln T. Tambusai & Hawai Store & - \\
8 & Jln T. Tambusai & Pelajar Interection & Expired \\
9 & Jln HR. Soebrantas & SD Tabek Gadang & Replaced \\
& & Interection & \\
10 & Jln HR. Soebrantas & Tabek Gadang Interection & Expired \\
11 & Jln HR. Soebrantas & Giant Store & \\
\hline
\end{tabular}

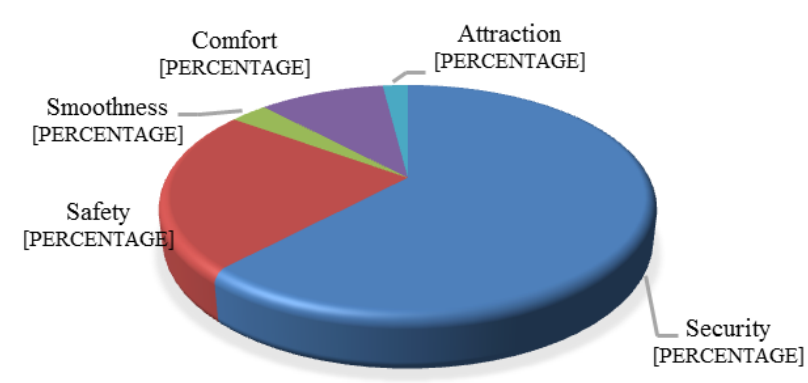

Figure 2. Utilization Consideration Factors 
Table 2. Respondents Related To Safety

\begin{tabular}{llcccccccc}
\hline \multirow{2}{*}{ Questions } & SS & S & CS & TS & STS & Val & Rate & Remark \\
& & $(5)$ & $(4)$ & $(3)$ & $(2)$ & $(1)$ & & & \\
\hline Signage & Freq. & 4 & 34 & 35 & 22 & 5 & 100 & 3,10 & CB \\
& Score & 20 & 136 & 105 & 44 & 5 & 310 & & \\
Surface & Freq. & 2 & 25 & 51 & 20 & 2 & 100 & 3,05 & CB \\
& Score & 10 & 100 & 153 & 40 & 2 & 305 & & \\
Railing & Freq. & 1 & 15 & 46 & 34 & 4 & 100 & 2,75 & CB \\
& Score & 5 & 60 & 138 & 68 & 4 & 275 & & \\
Rules \& & Freq. & 2 & 11 & 51 & 31 & 5 & 100 & 2,74 & CB \\
Guides & Score & 10 & 44 & 153 & 62 & 5 & 274 & & \\
Footpath & Freq. & 3 & 74 & 15 & 7 & 1 & 100 & 3,71 & B \\
& Score & 15 & 296 & 45 & 14 & 1 & 371 & & \\
Height & Freq. & 4 & 80 & 11 & 5 & 0 & 100 & 3,83 & B \\
& Score & 20 & 320 & 33 & 10 & 0 & 383 & & \\
\hline
\end{tabular}

Table 3. Responses Regarding Security

\begin{tabular}{|c|c|c|c|c|c|c|c|c|c|}
\hline & & & & s Res & nnse & & & & \\
\hline Quest & ons & $\begin{array}{l}\text { SS } \\
(5)\end{array}$ & $\begin{array}{c}\mathrm{S} \\
(4)\end{array}$ & $\begin{array}{l}\text { CS } \\
\text { (3) }\end{array}$ & $\begin{array}{l}\text { TS } \\
\text { (2) }\end{array}$ & $\begin{array}{c}\text { STS } \\
\text { (1) }\end{array}$ & Val & Rate & Remark \\
\hline$\overline{\text { Signage }}$ & $\begin{array}{l}\text { Freq. } \\
\text { Score }\end{array}$ & $\begin{array}{c}4 \\
20\end{array}$ & $\begin{array}{c}34 \\
136\end{array}$ & $\begin{array}{c}35 \\
105\end{array}$ & 22 & $\begin{array}{l}5 \\
5\end{array}$ & $\begin{array}{l}100 \\
310\end{array}$ & 3,10 & CB \\
\hline Surface & $\begin{array}{l}\text { Freq. } \\
\text { Score }\end{array}$ & $\begin{array}{c}2 \\
10\end{array}$ & $\begin{array}{c}25 \\
100\end{array}$ & $\begin{array}{c}51 \\
153\end{array}$ & $\begin{array}{l}20 \\
40\end{array}$ & $\begin{array}{l}2 \\
2\end{array}$ & $\begin{array}{l}100 \\
305\end{array}$ & 3,05 & $\mathrm{CB}$ \\
\hline Railing & $\begin{array}{l}\text { Freq. } \\
\text { Score }\end{array}$ & $\begin{array}{l}1 \\
5\end{array}$ & $\begin{array}{l}15 \\
60\end{array}$ & $\begin{array}{c}46 \\
138\end{array}$ & $\begin{array}{l}34 \\
68\end{array}$ & $\begin{array}{l}4 \\
4\end{array}$ & $\begin{array}{l}100 \\
275\end{array}$ & 2,75 & CB \\
\hline Rules \& & Freq. & 2 & 11 & 51 & 31 & 5 & 100 & 2,74 & $\mathrm{CB}$ \\
\hline $\begin{array}{l}\text { Guides } \\
\text { Footpath }\end{array}$ & $\begin{array}{l}\text { Score } \\
\text { Freq. }\end{array}$ & $\begin{array}{c}10 \\
3\end{array}$ & $\begin{array}{l}44 \\
74\end{array}$ & $\begin{array}{l}153 \\
15\end{array}$ & $\begin{array}{c}62 \\
7\end{array}$ & $\begin{array}{l}5 \\
1\end{array}$ & $\begin{array}{l}274 \\
100\end{array}$ & 3,71 & B \\
\hline Height & $\begin{array}{l}\text { Score } \\
\text { Freq. } \\
\text { Score }\end{array}$ & $\begin{array}{c}15 \\
4 \\
20\end{array}$ & $\begin{array}{c}296 \\
80 \\
320\end{array}$ & $\begin{array}{l}45 \\
11 \\
33\end{array}$ & $\begin{array}{c}14 \\
5 \\
10\end{array}$ & $\begin{array}{l}1 \\
0 \\
0\end{array}$ & $\begin{array}{l}371 \\
100 \\
383\end{array}$ & 3,83 & B \\
\hline & & & & & & & Mean & 3,20 & CB \\
\hline
\end{tabular}

Table 4. Responses About Comfort

\begin{tabular}{|c|c|c|c|c|c|c|c|c|c|}
\hline \multicolumn{9}{|c|}{ User's Response } & \\
\hline \multicolumn{2}{|c|}{ Questions } & \multirow{2}{*}{$\begin{array}{c}\text { SS } \\
(5)\end{array}$} & \multirow{2}{*}{$\begin{array}{c}S \\
(4) \\
65\end{array}$} & \multirow{3}{*}{$\begin{array}{c}\text { CS } \\
(3) \\
29 \\
87\end{array}$} & \multirow{3}{*}{$\begin{array}{c}\text { TS } \\
(2) \\
5 \\
10\end{array}$} & \multirow{2}{*}{$\begin{array}{c}\text { STS } \\
\text { (1) } \\
0\end{array}$} & \multirow{2}{*}{$\begin{array}{c}\text { Val. } \\
100\end{array}$} & \multirow{3}{*}{$\begin{array}{l}\text { Rate } \\
3,62\end{array}$} & \multirow{3}{*}{ 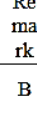 } \\
\hline Wide & Freq. & & & & & & & & \\
\hline & Score & 5 & 260 & & & 0 & 362 & & \\
\hline \multirow[t]{2}{*}{ Footstep } & Freq. & 1 & 48 & 43 & 5 & 3 & 100 & \multirow[b]{2}{*}{3,39} & \multirow[b]{2}{*}{ B } \\
\hline & Score & 5 & 192 & 129 & 10 & 3 & 339 & & \\
\hline \multirow{2}{*}{$\begin{array}{l}\text { Number } \\
\text { footstep }\end{array}$} & Freq. & 10 & 74 & 13 & 3 & 0 & 100 & \multirow{2}{*}{3,91} & \multirow{2}{*}{ B } \\
\hline & Score & 50 & 296 & 39 & 6 & 0 & 391 & & \\
\hline \multirow[t]{2}{*}{ Roof } & Freq. & 2 & 5 & 51 & 33 & 9 & 100 & \multirow[t]{2}{*}{2,58} & \multirow[t]{2}{*}{ TB } \\
\hline & Score & 10 & 20 & 153 & 66 & 9 & 258 & & \\
\hline \multirow[t]{4}{*}{ Rubbish } & Freq. & 2 & 2 & 47 & 38 & 11 & 100 & \multirow{2}{*}{2,46} & \multirow{2}{*}{ TB } \\
\hline & Score & 10 & 8 & 141 & 76 & 11 & 246 & & \\
\hline & Freq. & 4 & 47 & 32 & 16 & 1 & 100 & & \\
\hline & Score & 20 & 188 & 96 & 32 & 1 & 337 & 3,37 & B \\
\hline \multirow[t]{2}{*}{ Const. } & Freq. & 4 & 47 & 32 & 16 & 1 & 100 & \multirow{2}{*}{2,64} & \multirow{2}{*}{$\mathrm{CB}$} \\
\hline & Score & 5 & 76 & 99 & 74 & 10 & 264 & & \\
\hline \multirow[t]{2}{*}{ Bin } & Freq. & 1 & 3 & 31 & 55 & 10 & 100 & \multirow{2}{*}{2,30} & \multirow{2}{*}{ TB } \\
\hline & Score & 5 & 12 & 93 & 110 & 10 & 230 & & \\
\hline \multirow[t]{2}{*}{ Safety } & Freq. & 1 & 22 & 46 & 27 & 4 & 100 & \multirow{2}{*}{2,89} & \multirow{2}{*}{$\mathrm{CB}$} \\
\hline & Score & 5 & 88 & 138 & 54 & 4 & 289 & & \\
\hline \multirow[t]{2}{*}{ Cleannes } & Freq. & 1 & 3 & 40 & 48 & 8 & 100 & & \\
\hline & Score & 5 & 12 & 120 & 96 & 8 & 241 & 2,41 & IB \\
\hline Damages & Freq. & 26 & 23 & 31 & 20 & 0 & 100 & & \\
\hline & Score & 130 & 92 & 93 & 40 & 0 & 355 & 3,35 & B \\
\hline & & & & & & & Mean & 3,01 & $\mathrm{CB}$ \\
\hline
\end{tabular}

Table 5. Responses About Smoothness

\begin{tabular}{llcccccccc}
\hline \multicolumn{1}{c}{ Questions } & SS & S & CS & TS & STS & Val & Rate & Remark \\
& & $(5)$ & $(4)$ & $(3)$ & $(2)$ & $(1)$ & $\cdot$ & & \\
\hline Street & Freq. & 7 & 10 & 37 & 45 & 1 & 100 & 2,77 & CB \\
vendor & Score & 35 & 40 & 111 & 90 & 1 & 277 & & \\
Homeless & Freq. & 4 & 4 & 37 & 54 & 1 & 100 & & TB \\
& Score & 20 & 16 & 111 & 108 & 1 & 256 & 2,56 & \\
People & Freq. & 0 & 17 & 43 & 40 & 0 & 100 & & \\
sitting & Score & 0 & 68 & 129 & 80 & 0 & 277 & 2,77 & CB \\
Access & Freq. & 6 & 51 & 37 & 6 & 0 & 100 & 3,57 & B \\
& Score & 30 & 204 & 111 & 12 & 0 & 357 & & \\
& & & & & & & Mean & 2,92 & CB \\
\hline
\end{tabular}

Table 6. Responses About Attraction

\begin{tabular}{llcccccccc}
\hline \multicolumn{1}{c}{ Questions } & SS & S & CS & TS & STS & Val & Rate & \multirow{2}{*}{ Remark } \\
& & $(5)$ & $(4)$ & $(3)$ & $(2)$ & $(1)$ & $\cdot$ & & \\
\hline Strect & Freq. & 7 & 10 & 37 & 45 & 1 & 100 & 2,77 & CB \\
vendor & Score & 35 & 40 & 111 & 90 & 1 & 277 & & \\
Homeless & Freq. & 4 & 4 & 37 & 54 & 1 & 100 & & TB \\
& Score & 20 & 16 & 111 & 108 & 1 & 256 & 2,56 & \\
People & Freq. & 0 & 17 & 43 & 40 & 0 & 100 & & \\
sitting & Score & 0 & 68 & 129 & 80 & 0 & 277 & 2,77 & CB \\
Access & Freq. & 6 & 51 & 37 & 6 & 0 & 100 & 3,57 & B \\
& Score & 30 & 204 & 111 & 12 & 0 & 357 & 2,92 & CB \\
& & & & & & & Mean & 2,92 & \\
\hline
\end{tabular}

From field data, respondents showed a positive response to the physical condition of the pedestrian bridge. The answer has indicated that the mean assessment of 3.01, which implies seven of the eleven indicators of comfort are categorized as suitable and sufficient (Table 4). However, the comfort level of the pedestrian bridge use can also be affected by hygiene indicators that have directly correlate with the comfort level of the pedestrian bridge users.

The analysis shows that of the four indicators of fluency, there is one indicator that is in the wrong category, namely beggars/homeless at the pedestrian bridge. They generally take place in a position on the stairs, not on the crossing of the floor because the condition of the pedestrian bridge floor is usually in a damaged / porous condition (table $5)$.

The other two indicators are in the quite good category, namely street vendors, and people are sitting on the pedestrian bridge crossing body and the pedestrian bridge steps to wait for public transportation. This condition is more due to the existence of bus stops which are very close to the pedestrian bridge. Of course, this condition is alarming for the smooth operation of the pedestrian bridge users.

There are two out of three indicators of attractiveness in the wrong category, only one indicator in the good type, namely the availability of space for banners, billboards, and running text. The average score for the attractiveness indicator for the pedestrian bridge users is only 2.89 , and this can be categorized quite well. With the current, the pedestrian bridge condition, respondents' responses in general about the pedestrian bridge design are in the unattractive category (table 6). Situations like this are made worse by the absence of lighting for night-time needs.

The field data also show that the user response in utilizing the pedestrian bridge is in the quite good category with a score of 2.90. However, one of the five indicators of user response shows that the division is not right, namely the user's response to security conditions when using the pedestrian bridge (table 7). The shape of the pedestrian bridge began to be felt unfit for use, the lighting did not function properly, and the unavailability of CCTV to monitor security vulnerabilities along the pedestrian bridge.

Following its use, the pedestrian bridge is used to cross from one place to another. The pedestrian bridge has intended so that the flow of people and vehicle traffic can run well without any conflicting use of public access. The pedestrian bridge has considered being a right alternative 
crossing solution for pedestrians. There are five main factors user considerations in the use of the pedestrian bridge. Most users use the pedestrian bridge more due to security factors $(62 \%)$ to reduce the risk of traffic accidents. However, if it is related to the current condition of the pedestrian bridge, it is still far from the expectations of the pedestrian bridge users.

As a suggestion for crossing people, the pedestrian bridge provides positive benefits for pedestrians. The pedestrian bridge makes it easy for pedestrians to cross to avoid crossing directly with vehicles that ultimately impact the risk of accidents. The inaccuracy of pedestrians using the pedestrian bridge as a means of crossing is more due to the pedestrian bridge 's current physical condition, which is worrying following the response of users with an average score of 2.90, which includes enough categories. On the other hand, pedestrians are more concerned with safety factors while still choosing to use the pedestrian bridge to cross the road regardless of the physical condition of the pedestrian bridge.

The user response can stimulate by two factors; internal factors and external factors. Internal factors are influenced by the user's self-character. In this case, individual perceptions have constructed about the pedestrian bridge and consideration of their use. At the same time, external factors have influenced by the environment, such as physical influence related to the pedestrian bridge facilities. User responses can be positive or negative. User responses in this study are found still in the positive category even though the scores are far from expectations. This response means that the pedestrian bridge in Pekanbaru City is useable by pedestrians. However, this positive response with a low score should not ignore in the direction of a negative response, which means some fewer pedestrians want to use the existing pedestrian bridge.

Table 7. Recapitulation Of User's Responses

\begin{tabular}{|c|c|c|c|c|c|c|c|c|c|}
\hline \multicolumn{6}{|c|}{ User's Response } & & & & $\operatorname{Re}$ \\
\hline \multicolumn{2}{|c|}{ Theme } & $\begin{array}{l}\text { SS } \\
(5)\end{array}$ & $\begin{array}{c}S \\
(4)\end{array}$ & $\begin{array}{l}\text { CS } \\
\text { (3) }\end{array}$ & $\begin{array}{l}\text { TS } \\
\text { (2) }\end{array}$ & $\begin{array}{l}\text { STS } \\
\text { (1) }\end{array}$ & Val. & Rate & $\begin{array}{c}\mathrm{ma} \\
\mathrm{rk}\end{array}$ \\
\hline Safety & $\begin{array}{l}\text { Freq. } \\
\text { Score }\end{array}$ & $\begin{array}{c}3 \\
15\end{array}$ & $\begin{array}{c}40 \\
160\end{array}$ & $\begin{array}{c}35 \\
105\end{array}$ & $\begin{array}{l}20 \\
40\end{array}$ & 2 & $\begin{array}{l}100 \\
322\end{array}$ & 3,22 & CB \\
\hline Security & $\begin{array}{l}\text { Freq. } \\
\text { Score }\end{array}$ & $\begin{array}{c}2 \\
10\end{array}$ & $\begin{array}{l}11 \\
44\end{array}$ & $\begin{array}{l}32 \\
96\end{array}$ & $\begin{array}{l}45 \\
90\end{array}$ & $\begin{array}{c}10 \\
0\end{array}$ & $\begin{array}{l}100 \\
250\end{array}$ & 2,50 & TB \\
\hline Comfort & $\begin{array}{l}\text { Freq. } \\
\text { Score }\end{array}$ & $\begin{array}{c}5 \\
25\end{array}$ & $\begin{array}{c}28 \\
112\end{array}$ & $\begin{array}{c}36 \\
108\end{array}$ & $\begin{array}{l}26 \\
52\end{array}$ & $\begin{array}{l}5 \\
5\end{array}$ & $\begin{array}{l}100 \\
302\end{array}$ & 3,02 & $\mathrm{CB}$ \\
\hline Smoothness & $\begin{array}{l}\text { Freq. } \\
\text { Score }\end{array}$ & $\begin{array}{c}2 \\
10\end{array}$ & $\begin{array}{l}21 \\
84\end{array}$ & $\begin{array}{c}40 \\
120\end{array}$ & $\begin{array}{l}37 \\
74\end{array}$ & $\begin{array}{l}0 \\
0\end{array}$ & $\begin{array}{l}100 \\
288\end{array}$ & 2,88 & CB \\
\hline Attraction & $\begin{array}{l}\text { Freq. } \\
\text { Score }\end{array}$ & $\begin{array}{l}1 \\
5\end{array}$ & $\begin{array}{l}22 \\
88\end{array}$ & $\begin{array}{c}49 \\
147\end{array}$ & $\begin{array}{l}21 \\
42\end{array}$ & $\begin{array}{l}7 \\
7\end{array}$ & $\begin{array}{l}100 \\
289\end{array}$ & 2,89 & CB \\
\hline & & & & & & & Mean & 2,90 & CB \\
\hline
\end{tabular}

\section{CONCLUSION}

From this research, several conclusions can be drawn. Factors that influence users in utilizing the pedestrian bridge in Pekanbaru City have based on consideration, in sequence, a security factor of $62 \%$, a safety factor of $23 \%$, a comfort factor of $10 \%$, a smoothness factor of $3 \%$, and an attractiveness factor of $2 \%$.

Another conclusion that the inability of pedestrians to use the pedestrian bridge as a crossing facility due to the pedestrian bridge 's current physical condition, which is worrying because the available facilities are far from the user's expectations. This reason has evidenced by the response of the pedestrian bridge users with an average value of 2.90, which is only in the sufficient category. In another response shows, pedestrians are more concerned with safety factors but still choose to use the pedestrian bridge regardless of the physical condition of the current pedestrian bridge.

\section{ACKNOWLEDGMENT}

The research team would like to thank the Ministry of Research and Technology / National Research and Innovation Agency, Deputy for Research and Development Strengthening for providing support to this research through Non-PTNBH Higher Education Research Funding through the Master Thesis Research (PTM) scheme in 2020.

\section{REFERENCES}

[1] Nejur. Andrei, \& Mireea. Calin GR., 2012. Morphology and Urban Planning of a Pedestrian Bridge. Proceeding IASS-APCS From Spatial Structures to Space Structure. pp. 389 - 397

[2] Eka Agus Sugito., 2017. Tingkat Pemanfaatan dan Faktor Yang Mempengaruhi Pemakaian Jembatan Penyeberangan Orang Di Depan Mega Mall Jalan A.Yani Kota Pontianak, Fakultas Teknik Sipil, UNTAN. Hal. 2.

[3] Ashur, S., \& Alhassan, M. 2015. Selection of pedestrian crossing treatments at controlled and uncontrolled locations (Joint Transportation Research Program Publication No. FHWA/IN/JTRP-2015/03) West Lafayette, IN: Purdue University. http://dx.doi.org/10.5703/1288284315522

[4] Jain. Akash., Gupta. Ankit., Rastogi. Rajat., 2014. Pedestrian Crossing Behaviour Analysis At Intersections. International Journal for Traffic and Transport Engineering, 4(1): 103 - 116

[5] Sugito, Eka Agus., Syafaruddin., Nurlaily, Siti. 2018. Tingkat Pemanfaatan dan Faktor yang Mempengaruhi Pemakaian Jembatan Penyeberangan Orang di Depan Mega Mall Jalan A.Yani Kota Pontianak. Jurnal Mahasiswa Teknik Sipil Universitas Tanjungpura. 5(1): 1-15.

[6] Anciaes. Paulo Rui., \& Jones. Peter., 2017. Estimating preferences for different types of pedestrian crossing facilities. Transportation Research Part F 52. pp. 222-237

[7] Mako. Emese and Szakonyi. Petra., 2016. Evaluation of human behaviour at pedestrian crossings. Transportation Research Procedia 14. pp. 2121 2128

[8] Nuggraeni, Herlinsta Astrie. 2006. Efektifitas Penggunaan Jembatan Penyeberangan Orang (JPO) dan Variabel-Variabel yang Mempengaruhi Penyeberang Jalan Dalam Menggunakannya, Studi 
Kasus Kota Semarang. Skripsi, Universitas

Diponegoro.

[9] Koswara, Edy Upriady. 2014. Efektifitas Penggunaan Fasilitas Jembatan Penyeberangan Orang (JPO), Studi Kasus Pada Fasilitas Jembatan Penyeberangan Orang Di Jl. Soekarno Hatta Bandung. Jurnal Konstruksi. 12(1): 1-5

[10] Indraswara, M.Sahid. 2006. Kajian Perilaku Pejalan Kaki Terhadap Pemanfaatan Jembatan Penyeberangan. ENCLOSURE Jurnal Ilmiah Perancangan Kota dan Permukiman. 5(2).

[11] Isya, M., Irin, Caisarina., Etty, Herawaty. 2015. Aksesibilitas Jembatan Penyeberangan Orang (JPO) bagi Penyandang Difable di Kota Banda Aceh Menurut Persepsi Masyarakat. Jurnal Teras. 5(1): 1220.

[12] Silvia, Novita. 2018. Respon Penyeberang Jalan Terhadap Fasilitas JPO Di Kota Pekanbaru. Jurnal Online Mahasiswa Universitas Riau.

[13] Soenarjo dan Djoenarsih S. Soenajo., 1983. Himpunan Istilah Komunikasi, Yogyakarta: Liberty

[14] Abojaradeh. Mohammad., 2013. Evaluation of Pedestrian Bridges and Pedestrian Safety in Jordan. Civil and Environmental Research, 3 (1): 66 - 78

[15] Ahmad, Furchan., 2004. Pengantar Penelitian Dalam Pendidikan. Yogyakarta. Pustaka Belajar

[16] Wibisono, Dermawan. 2003. Riset Bisnis: Panduan Bagi Praktisi dan Akademis, PT. Gramedia Pustaka Utama, Jakarta.

[17] Sugiyono. 2008. Metodologi Penelitain Kuantitatif, Edisi kedua.

[18] Herdiansyah, Jefri. 2012. Pengaruh Advertising Terhadap Pembentukan Brand Awareness Serta Dampaknya Pada Keputusan Pembelian Produk Kecap Pedas ABC. Jurnal STIE Semarang, Vol 4(2), ISSN. 22527826.

[19] Arikunto, Suharsimi. 2010. Prosedur Penelitian Suatu pendekatan Praktek. Jakarta. Rineka Cipta.

[20] Priyatno. 2008. Mandiri Belajar SPSS - Bagi Mahasiswa dan Umum. Yogyakarta : MediaKom.

[21] Maurya. Akhilesh Kumar., \& Panda. Jagannath., 2015. Study of pedestrian movement over foot over bridge. Discovery, 40(182): 104-117

[22] Braga. Antonio., Pinto. Hugo JR., Teixeira. Joana P., Azevendo., Alvaro., 2008. Design of a Pedestrian Bridge in a Historical Spot. Proceeding Third International Conference. Porto - Portugal

[23] Rasanen. Mikko., Lajunen. Timo., Alticafarbay. Farahnaz., Aydin. Cumhur., 2007. Pedestrian selfreports of factors influencing the use of pedestrian bridges. Accident Analysis and Prevention 39: 969973 